\title{
РЕПРЕЗЕНТАЦІЯ СЕКСУАЛЬНОГО НАСИЛЬСТВА В УКРАЇНСЬКІЙ РАДЯНСЬКІЙ ПРЕСІ 1920-1930-х РОКІВ: ІДЕОЛОГІЧНИЙ КОНТЕКСТ
}

\author{
Ольга Хамедова \\ Киівський університет імені Бориса Грінченка \\ вул. Маршала Тимошенка, 13 Б, 04212, Київ, Украӥна \\ e-mail: kubg@kubg.edu.ua \\ https://orcid.org/0000-0002-9545-4464
}

У статті досліджується специфіка висвітлення сексуального насильства в українській радянській пресі 1920-1930-х років, зокрема такі його форми, як згвалтування і сексуальні домагання. Об'єктом дослідження стали судові репортажі, повідомлення кримінальної хроніки, кореспонденції, статті, присвячені цій темі і вміщені у газетах і журналах 1920-1930-х років. Сексуальні злочини були табуйованою і маргіналізованою темою в українській радянській пресі: журналісти здійснювали специфічний відбір фактів і оприлюднювали лише ті з них, які могли прислужитися радянській пропаганді. Підкреслюється, що комуністична ідеологія впливала на зміст, типологію персонажів, інтерпретацію події, визначала ідейні акценти таких повідомлень.

Key words: сексуальне насильство; гендерне насильство; згвалтування; преса; пропаганда; ідеологія.

\section{1. Постановка проблеми}

Проблема гендерного насильства, на жаль, залишається актуальною і в Україні, і в усьому світі. Проте, на думку багатьох медіадослідників, ця проблема є замовчуваною або маргіналізованою у публічних дискурсах, у тому числі медійному: «В Україні статеве насильство залишається малодискутованою темою, говорити про яку вважається соромно, непристойно. Воно потрапляє в центр медійної уваги лише тоді, коли супроводжується іншими тяжкими злочинами - каліцтвом потерпілих або убивством» ${ }^{1}$.

Більшовики визначали жіночу рівноправність одним із пріоритетних завдань у багатьох документах. Проте їхньою стратегічною метою було залучити до революційної боротьби якнайбільше жінок, виховати 3 них ідейних комуністок, відданих радянській владі, і в такий спосіб зміцнити й утвердити їі. Тому у 1920-і роки було

\footnotetext{
1 Маєрчик, М., Плахотнік, О. (2014), «Гендероване насильство: між звичаєм і злочином». М. Маєрчик, О. Плахотнік, Г. Ярманова (Ред.). Гендер для медій. Підручник із гендерної теорії для журналістики та інших соціогуманітарних спещіальностей. Київ, Критика, с. 162.
}

(C) Хамедова О., 2020 
розпочато «більшовицький емансипаційний проект» (М. Вороніна) ${ }^{2}$ : це була низка заходів, спрямованих на інтеграцію жінки до громадського (партійного передусім) життя та масового залучення жіноцтва до виробничої діяльності. Цьому сприяло утворення жіночих відділів і посади жінорганізаторки у партійних осередках усіх рівнів, регулярні проведення зібрань жінок-делегаток, кампанії із залучення домогосподарок, дружин робітників, до суспільно корисної діяльності тощо. Таким чином, комуністи взяли під контроль феміністичний рух, а діяльність громадських активісток була спрямована у потрібне партії річище.

У провідних громадсько-політичних часописах висвітлювалися питання соціальної ролі жінки, значення шлюбу і сім'ї у руслі комуністичної ідеології. Про сексуальне насильство, якого зазнавали жінки, преса також інформувала у різножанрових публікаціях (новинні повідомлення, кореспонденції, судові репортажі та ін.). Актуальність нашого дослідження зумовлена тим, що репрезентація сексуального насильства в українській пресі до сьогодні є малодискутованою і маргінальною темою в науковому дискурсі.

\section{2. Теоретичне підгрунтя}

Гендерні медійні студії у західній науковій традиції вже мають значні здобутки, адже дослідження тривають 3 1960-х років. Напрямки досліджень визначають різні види медій: в гендерному аспекті аналізуються кіно, телебачення, радіо, реклама, музична індустрія, преса. 3 іншого боку, сфера гендерних досліджень виявляє увагу до різних складових комунікативної моделі комунікатор - повідомлення - аудиторія.

Гендерні медійні студії в Україні $є$ відносно новим і перспективним науковим напрямком, започаткованим у $2000-\mathrm{x}$ роках. Важливою теоретичною розробкою вважаємо колективну працю «Гендер для медій» (2014) за редакцією Марії Маєрчик, Ольги Плахотнік і Галини Ярманової. У світлі досліджуваної проблеми значущим для нас $\epsilon$ розділ цієї праці «Гендероване насильство: між звичаєм і злочином» ${ }^{3}$, в якому згвалтування розглядається як вияв гендерного насильства і показується як «культура згвалтування», вбудована у суспільні інституції, звичаї і традиції; при цьому наголошується на проблемах висвітлення сексуального насильства щодо жінок у $3 \mathrm{MI}$.

Однією з актуальних розвідок у цьому аспекті є праця Терези де Лауретіс «Риторика насильства. Роздуми про репрезентацію і гендер». Дослідниця підкреслювала, що «репрезентація насильства нерозривно пов'язана 3 поняттям гендеру, іншими словами, я стверджую, що насильство народжується в репрезентації» ${ }^{4}$. Вона доводила, що у відтворенні соціальних практик насильства має значення його мовне конструювання: так окремі риторичні прийоми і мовні стратегії застосовуються у текстах, щоб приховати факти сімейного насильства чоловіків щодо жінок, відволікти увагу аудиторію, виправдати насильство. Дослідниця Дж. Нейджел також ви-

\footnotetext{
2 Вороніна, М. (2017), Більшовицький емансипаційний експеримент у 1920-х роках. Кісь О. (Ред.). Українські жінки у горнилі модернізаиії. Харків, Клуб сімейного дозвілля, с. 106-131.

3 Маєрчик, М., Плахотнік, О. (2014), «Гендероване насильство: між звичаєм і злочином». М. Маєрчик, О. Плахотнік, Г. Ярманова (Ред.). Гендер для медій. Підручник із гендерної теорї для журналістики та інших соиіогуманітарних спеціальностей. Київ, Критика, 217 с.

4 Лауретис, де Т. (2000), Риторика насилия. Рассмотрение репрезентации и гендера. Гапова Е., Усманова А (Ред.). Антология гендерной теории. Минск, Пропилеи, 2000, с. 350-351.
} 
значала пріоритетним напрямком гендерних студій вивчення такої «явно гендерної діяльності, як злочин ...чи насильство», в якій жінка є жертвою «неадекватної маскулінності» 5 .

Наразі актуальним напрямком гендерних медійних студій $є$ ті розвідки, в яких досліджується специфіка висвітлення у мас-медіа взаємозв'язків мілітаризму і гендерного насильства. Українська радянська преса 1920-1930-х зафіксувала факти насильства військових над цивільними жінками під час воєнних конфліктів першої третини XX століття. Зважаючи на поточні міжнародні воєнні конфлікти і загрози тероризму, дослідники, наприклад, Дж.Батлер у нещодавно перекладеній в Україні праці «Frames of War. When is life grievable?» («Фрейми війни. Чиї життя оплакують?») ${ }^{6}$, вивчають ідеологічний фокус медійного подання цих проблем, приховані вияви гендерної, расової, національної ворожнечі у західних мас-медіа.

\section{3. Методологічна основа дослідження}

Гендерні медійні студії використовують методологію, притаманну міждисциплінарним дослідженням, які виникли на перетині медійних, культурних і гендерних студій. Найпопулярнішими, на думку Д. Мак-Квейла, є «літературні, дискурсивні і

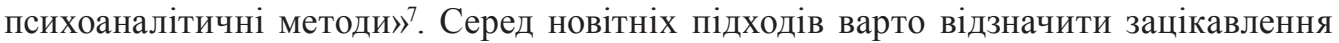
науковців дискурс-аналізом, який застосовував для аналізу новин нідерландський дослідник мови ЗМІ Т. ван Дейк у 1980-х роках. Філософським джерелом цього методу стала концепція соціального конструктивізму, яка вплинула на розвиток сучасної науки, особливо гуманітаристики і соціальних комунікацій. Український лінгвіст О. Семотюк указав на відмінність цього наукового методу від інших: «Якщо інші якісні методи дослідники використовують для інтерпретації дійсності такою, якою вона є на даний момент, то аналіз дискурсу намагається відшукати спосіб, у який ця дійсність була сконструйована» ${ }^{8}$.

М. М. Лазар переконливо довела необхідність синтезу феміністичного підходу з критичним дискурс-аналізом при дослідженні соціальних практик жіноцтва та висвітлення їх у пресі, адже це дає змогу виявити приховані механізми «комплексної взаємодії влади та ідеології у дискурсі для підтримки гендерної соціальної ієрархії»9. Тому, на нашу думку, дискурс-аналітичний підхід варто поєднати зі здобутками феміністичного критицизму, який сфокусований на «дискурсних репрезентаціях гендеру, стратегіях формування рольових ідентифікацій» ${ }^{10}$.

Дискурс-аналіз дасть змогу нам з'ясувати, яку ідеологічну форму репрезентації соціального світу представляли журналістські публікації про гендерне насильство; який ідеологічний дискурс був панівним; у який спосіб встановлювався владний

5 Нейджел, Дж. (2003), «Маскулінність та націоналізм; гендер та сексуальність у творенні націй», Гентош Л., Кісь О. (Ред.), Гендерний підхід: історія, культура, суспільство. Львів, ВНТЛ-Класика, с. 182-205.

6 Батлер, Дж. (2016), Фрейми війни. Чиї життя оплакують? Київ, Медуза, 276 с.

7 Мак-Квейл, Д. (2010), Теорія масової комунікації. Львів, Літопис, с. 308.

8 Семотюк, O. (2015), «Аналіз дискурсу vs. контент-аналіз: методично-методологічні відмінності і подібності», Людина. Комп'ютер. Комунікація: збірник наукових пращь, Львів, Вид-во Львівської політехніки, с. 79 .

9 Lazar, M. M (2007), «Feminist Critical Discourse Analysis. Articulating a feminist discourse praxes». https://www.tandfonline.com/doi/abs/10.1080/17405900701464816 (accessed 30 Oktober 2019)

${ }^{10}$ Павлюк, Л. С. (2007), Риторика, ідеологія, персуазивна комунікація. Львів, ПАІС, с. 17. 
режим в координатах домінування - субординації. За допомогою феміністичного підходу проаналізуємо гендерну картину світу, яку представляла українська радянська преса 1920-1930-х років читацькій аудиторії і визначимо технології гендерованого медіатексту.

\section{4. Виклад основного матеріалу дослідження.}

Українська радянська преса 1920-1930-х років зафіксувала деякі факти гендерного насильства над жінками. При цьому варто уточнити поняття гендерного насильства: «такі форми насильницьких дій, що мають чітко виражену гендерну групу, на яку це насилля спрямоване або яка це насилля чинить» ${ }^{11}$, одними з його форм є сексуальні домагання і згвалтування. Помітною є така тенденція у повідомленнях про сексуальне насильство у пресі 1920-х років: повідомлялося лише про ті згвалтування, які закінчувалися фатально для жертви, тобто смертю. Судовий репортаж «Наймичина доля» (тут і надалі тогочасний правопис збережено - О. Х.) було уміщено у київській щоденній газеті «Пролетарська правда» (за 6 листопада 1925 р.) у рубриці «Червоний суд». «Куркуля» Степана Михайлюка судили за сексуальні домагання до наймички Мотрі Бронської, примус її до сексуального зв’язку, а двох жінок, за проведення нелегального аборту Мотрі, який призвів до їі смерті. У репортажі розповідалося про наймичку Мотрю, яка зазнала сексуальних переслідувань у «куркульській родині»: «молодий господар Степан Михайлюк став не давати проходу дівчині, щоб вона жила з ним як з чоловіком»; «кожен день до неї приставав молодий господар зі своїми ганебними пропозиціями» ${ }^{12}$.

Важливими тут $є$ функції заголовка: він водночас інформував про класову приналежність героїні, її важке життя та створював відповідне емоційно-експресивне тло історії. Т. ван Дейк стверджував, що «заголовок тексту і яка є в основі його семантична репрезентація містить поняття, які можуть слугувати для активації основних моделей даного тексту» ${ }^{13}$. Емоційний вплив був можливим тому, що автор спирався на контекстні знання своєї читацької аудиторії про тяжке життя наймичок, тому формулювання «наймиччина доля» активувало ментальну модель ситуації, згідно з якою жорстокий і розбещений куркуль знущається над бідною наймичкою.

Таким чином, у медійному дискурсі журналіст один із перших розкрив проблему сексуальних домагань, які у сучасному українському законодавстві визначаються як «дії сексуального характеру, виражені словесно (погрози, залякування, непристойні зауваження) або фізично (доторкання, поплескування), що принижують чи ображають осіб, які перебувають у відносинах трудового, службового, матеріального чи іншого підпорядкування» [c.163]. На той час вони не кваліфікувалися як злочин, тому і терміну окремого не було, а журналіст використав наступні формулювання: «ганебні пропозиції», «став не давати проходу дівчині».

Матеріали про сексуальні домагання справді були достатньо революційними, оскільки до цього у пресі були лише поодинокі повідомлення про згвалтування. Незважаючи на відвертість в оприлюдненні факту домагань, щодо згвалтування жур-

\footnotetext{
${ }^{11}$ Маєрчик, М., Плахотнік, О. (2014), «Гендероване насильство: між звичаєм і злочином». М. Маєрчик, О. Плахотнік, Г. Ярманова (Ред.). Гендер для медій. Підручник із гендерної теорії для журналістики та інших соиіогуманітарних спеиіальностей. Київ, Критика, с. 153.

12 «Наймичина доля» (1925), Пролетарська правда. 6 листопада, вип. 255 (1266), с. 3.

${ }_{13}$ Дейк ван, Т. (2000), Язык. Познание. Коммуникаиия. БГК им. И.А. Бодуэна де Куртенэ, Благовещенск, 308 с.
} 
наліст був обережний у висловлюваннях: «Якось у травні місяці 1924 року, коли Мотря спала в клуні, до неї прийшов Степан й оволодів нею» ${ }^{14}$. У лінгвістичній патріархатній традиції сексуальний зв'язок характеризується через категорії влади: статевий акт розуміється як вияв влади чоловіка і підлеглості жінки, тому вираз «оволодів нею» є традиційним для добровільного статевого акту, але не відповідним для визначення примусового. Очевидно, що йдеться про примус до сексуального контакту, який призвів до вимушеного тривалого сексуального зв'язку наймички 3 господарем: «з цього часу вони стали спати як чоловік і жінка»»

У справі про жертву-наймичку очевидними були ідеологічні «дивіденди» радянської влади, тому справа була максимально відкрита для громадськості і висвітлювалася у пресі: «Справу цю слухали показовим процесом протягом чотирьох вечорів у клубі друкарів. Кожен вечір клуб був переповнений робітниками. Особливо робітниці уважно стежили за ходом справи» $\rangle^{16}$. Промовистим було останнє зауваження щодо зацікавлених робітниць, чию увагу привернула насамперед гендерна складова цього процесу. Очевидно, що більшість робітниць або безпосередньо стикалася iз сексуальними домаганнями і насильством на роботі, або принаймні знали про такі інциденти від інших жінок. Окремих публікацій, присвячених темі сексуальних домагань, в українській пресі 1920-1930-х років не було, проте траплялися обережні згадки або прозорі натяки на них у публікаціях іншої тематики. Приміром, журналіст газети «Пролетарська правда» (стаття, підписана криптонімом Н. Н.) у рубриці «Серед робітниць» у статті «У цукроварні (м. Іллінці)» розповів про те, що жінки масово приходять з навколишніх сіл на цукроварню у пошуках роботи. Чоловіки-керівники фабрики кваліфікували робітниць як потенційні сексуальні об’єкти: «Узагалі було багато нарікання й плачу, як приймали. Траплялись «грішки»... Дивились не на те, чи людина бідує, а на «гарні оченята» ${ }^{17}$.

Своєю чергою у судовому репортажі журналіст по-іншому розставляв ідейні акценти. Він підкреслив те, що Мотря Бронська походила з бідної родини, яка емігрувала з Польщі до Радянського Союзу. За допомогою художніх засобів (риторичних запитань, градації і гіпербол) журналіст наголосив на тяжкому становищі цієї родини і викликав жаль та співчуття до дівчини: «чи може хто переказати все те злиднування, якого зазнали ці сироти? Кожен день вони шукали праці, кожен день просилися на роботу, щоб запрацювати собі на шматок хліба. I кожен раз їм відмовляли» ${ }^{18}$. Саме страхом залишитися без роботи автор пояснив і кількамісячні сексуальні контакти з хазяїном: «Хотіла Мотря покинути службу, але страх перед голодуванням примусив її й далі працювати у хазяїна» ${ }^{19}$.

Таким чином, журналіст вдався до технології фреймінгу. Дж. Батлер відзначала, що «фреймінг реальності - її звуження та інтерпретація водночас», і уточнювала, що «рамка не просто показує реальність, а активно бере участь у стратегії обмежування, вибірково продукуючи й нав'язуючи те, що вважатиметься реальністю» ${ }^{20}$.

\footnotetext{
${ }_{14}$ «Наймичина доля» (1925), Пролетарська правда. 6 листопада, вип. 255 (1266), с. 3.

15 «Наймичина доля» (1925), Пролетарська правда. 6 листопада, вип. 255 (1266), с. 3.

16 Там само.

${ }^{17}$ Н. Н., (1925). «У цукроварні (м.Іллінці)», Пролетарська правда, 1 листопада, № 251 (1262), с. 4.

18 «Наймичина доля» (1925), Пролетарська правда. 6 листопада, вип. 255 (1266), с. 3.

19 Там само.

${ }^{20}$ Батлер, Дж. (2016), Фрейми війни. Чиї життя оплакують? Київ, Медуза, 276 с.
} 
Фрейм класової боротьби, накладений на цю історію, зумовлював сприйняття цього сексуального злочину реципієнтами крізь призму комуністичної ідеології.

Відзначимо, що тема сексуальних злочинів під час Першої світової війни, революції, громадянської війни була табуйованою у радянському інформаційному просторі до кінця XX століття, і лише одиниці наважувалися і1і порушувати. У західноукраїнській пресі міжвоєнного періоду були поодинокі публікації громадських активісток про травматичний сексуальний досвід під час війни. У радянській пресі деякі публікації про насильство над жінками під час Першої світової війни і громадянської війни з'являються лише у 1920-ті роки.

Одразу після встановлення радянської влади в Україні журналісти і письменники активно почали творитися міф про червоноармійців як визволителів українських пролетарів від буржуазних «петлюрівських» і «денікінських» військ. При цьому у жіночій пресі цей міф інтерпретували своєрідно, відповідно до інтересів своєї читацької аудиторії. Приміром, у миколаївській газеті «Работница и крестьянка» за 15 квітня 1920 р. була надрукована стаття «Як розправляються з жінками білогвардійці» (переклад з російської наш - О. Х.) про нібито масові згвалтування українських жінок білогвардійцями: «У Полтаві було згвалтовано понад 800 дівчат. У Козлові білі офіцери згвалтували поголовно майже всіх жінок» ${ }^{21}$. Така журналістська технологія залякування служила очевидній ідеологічній меті- переконати жіноцтво Миколаївщини під час громадянської війни підтримувати більшовиків. Таким чином, червоноармійці позиціонувалися як захисники жінок від статевого насильства з боку денікінців.

3’явилися у пресі і публіцистичні твори, своєрідні літописи участі у громадянській війні окремих дивізій, загонів Червоної Армії. До прикладу, у провідному літературно-мистецькому часописі «Червоний шлях» були опубліковані фрагменти 3 публіцистичної книги І. Дубинського «Війна та мир Запорозької дивізії», в якій оспівувалася переможна участь «червоного козацтва» у «найзапеклішій і найтяжчій боротьбі за робітничо-селянську владу на Україні» ${ }^{22}$ У розділі «Самокритика» автор згадав і ганебні сторінки цієї дивізії, зокрема сексуальні злочини, щодо яких він використав евфемізм «негарні вчинки». Дж. Нейджел слушно стверджувала, що «історії фактично з усіх воєн містять згадки і розповіді про гвалтування, сексуальне поневолення, або сексуальну експлуатацію жінок» ${ }^{23}$.

Відзначимо громадянську сміливість публіциста, який у часи сталінізму наважився розповісти про два випадки згвалтувань «червінцями» (червоними козаками) жінок: «В березні 1918 року два червінці згвалтували жінку. За звичаєм того часу, їх без ніякого суду розстріляли, скоро виявилося, що вони винні цього непристойного для козака вчинку» ${ }^{24}$. Чітка вказівка на дату підкреслювала, що автор хотів наголосити на тому, що такий випадок в історії дивізії був винятковим і злочинці були жорстоко покарані. Про інший сексуальний злочин автор розповів більш докладно,

${ }^{21}$ «Как расправляются с женщинами белогвардейцы» (1920), Работница и крестьянка. 15 апреля, вип. 3, с. 3.

22 Дубинський, I. (1929), «Війна і мир Запорозької дивізії», Червоний шляхх, вип. 12, с. 88.

${ }^{23}$ Нейджел, Дж. (2003), «Маскулінність та націоналізм; гендер та сексуальність у творенні націй», Гентош Л., Кісь О. (Ред.), Гендерний підхід: історія, культура, суспільство. Львів, ВНТЛ-Класика, с. 197.

${ }^{24}$ Дубинський, I. (1929), «Війна і мир Запорозької дивізії», Червоний шлях, вип. 12, с. 92. 
назвавши навіть ім’я винуватця: «у Галичині сотник Мозговий згвалтував робітницю якогось польського пана $»^{25}$. Звернемо увагу і на уточнення щодо території, i на вказівку щодо національності пана: ці деталі свідчили, що жінка у сприйнятті червоноармійців належала до ворожого табору. Дж. Нейджел, характеризуючи поведінку чоловіків на війні, підкреслювала, що «жінок з ворожого стану досить одностайно характеризують як розпусних та доступних: повії або законні об’єкти згвалтування $\rangle^{26}$. Водночас вона була наймичкою, представницею експлуатованого класу, а Червона армія мала символізувати справедливу боротьбу за щастя всіх знедолених трударів, тому цей злочин мав бути покараний показово. I безперечно, саме тому журналіст цей факт відібрав і про нього розповів.

Важливою є друга частина мікроструктури цього повідомлення, про реакцію на покарання всередині війська: частина козаків обурилася таким вироком і зчинила бунт.

У питанні про згвалтування йдеться насамперед про владу: сексуальне оволодіння жінкою ворога $є$ символічною перемогою над ворогом, виявом домінування над ним. Про це пише Я. Тешанович, проаналізувавши, як на Гаазькому трибуналі розглядали справи про статеве насильство під час югославської війни: «якщо гвалтування жінок було своєрідним підтвердженням права на територію чи підняттям прапора над нею, це доводить, що жінки зазнали тортур насамперед як жінки і що згвалтування $\epsilon$ передусім статевим злочином $)^{27}$.

I. Дубинський одним із перших в УСРР сказав відверто про наявність своєрідного сексуального «супроводу» червоноармійців («величезну кількість жінок не тільки у візках обозу, але й в тачанках дієвих частин») ${ }^{28}$. Факти статевого насильства у Червоній армії автор трактував як винятки із правил поведінки загалом високоморальних «червінців». Т. ван Дейк стверджував, що «головним у реалізації влади $\epsilon$ контроль над процесом соціального пізнання за допомогою керування знаннями та установками, передформування переконань, цензури опозиційної ідеології $\rangle^{29}$. Для «передформування переконань» читачів автор ще у преамбулі до книги налаштовував їх на «правильне» сприйняття зображуваних подій: «Значення цих перемог не можуть зменшити ті темні плями, які лягали на славне ім'я червоного козацтва від негарних вчинків окремих груп дезорганізованих бійців» ${ }^{30}$.

Представники мілітарних організацій наділені владною позицією не тільки у сенсі виконуваних ними службових обов'язків, але також у плані встановлення і підтримання гендерного режиму. Промовистою у цьому аспекті є замітка «За згвалтування арештованої», розміщена у рубриці «Червоний Суд» щоденної київської газети «Пролетарська правда» (4 липня 1925 р.), в якій розповідалося про те, що затриману на базарі перекупку Настю Бабенкову згвалтував міліціянт Яків Левченко. У тексті

${ }^{25}$ Там само.

${ }^{26}$ Нейджел, Дж. (2003), «Маскулінність та націоналізм; тендер та сексуальність у творенні націй», Гентош Л., Кісь О. (Ред.), Гендерний підхід: історія, культура, суспільство. Львів, ВНТЛ-Класика, с. 197.

27 Тешанович, Я. (2003), «Жінки і війна», Незалежний культурологічний часопис, № 27, с. 85

28 Дубинський, I. (1929), «Війна і мир Запорозької дивізії», Червоний шлях, вип. 12, с. 92.

29 Дейк ван, Т. (2013), Дискурс и власть. Репрезентация доминирования в языке и коммуникации. Либроком, Москва, с. 86.

${ }^{30}$ Дубинський, I. (1929), «Війна і мир Запорозької дивізії», Червоний шлях, вип. 12, с. 88. 
підкреслювався його владний статус: «Скориставшись із своєї влади над караулом як черговий у пункті, Левченко вивів Бабенкову з арештантського приміщення в

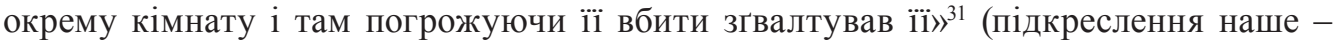
О. Х.). У цьому повідомленні журналіст пов’язав питання гендерного насильства 3 питанням соціальної влади між гендерними групами, вказавши на чоловічу позицію соціального домінування.

В умовах посилення ідеологічного тиску у 1930-х роках тему сексуальних злочинів стали висвітлювати у специфічний спосіб: повідомлялося лише про ті, які сталися за кордоном, причому у «буржуазних» країнах. Приміром, у центральній республіканській газеті «Вісті Центрального Виконавчого Комітету Рад Робітничих, Селянських та Червоноармійських Депутатів УССР» за 1931 рік була низка публікацій, присвячена переслідуванню комуністів у Польщі та жорстокому ставленню до політв’язнів. Щоб привернути увагу громадськості, їх друкували на першій сторінці 3 промовистими назвами, як-то «Новий шал польського фашизму», «Польський фашистський терор на Західній Україні лютує з неослабною силою» та ін. У кореспонденції «Польський фашистський терор на Західній Україні лютує з неослабною силою» йшлося про катування у луцькій тюрмі політв'язнів, з акцентом на гвалтуванні ув'язнених жінок-комуністок. І якщо у повідомленнях 1920-х років про сексуальне насильство, яке чинили радянські посадовці, уникали деталізованого опису, просто констатуючи факт згвалтування, то для створення довершеного образу «оскаженілих» капіталістів 1930-х років журналісти не шкодували чорної фарби, повідомляючи, наприклад, подробиці жорстоких знущань з ув'язненої робітниці Штіфтер. Г. Почепцов такі розповіді про знущання ворогів називає однією з найбільш ефективних пропагандистських технологій в інформаційній війні: «Пропаганда супротивника максимально «розкручує» такі ситуації. I довіра до них досить висока. Пояснити це, мабуть, можна тим, що в кризовій ситуації...люди починають реагувати на більш прості варіанти подразників» ${ }^{32}$.

\section{5. Результати і перспективи подалыших досліджень обговорення}

Після 1920-х років в українській радянській пресі (як республіканській, так і регіональній) про випадки статевого насильства, вчиненого міліціянтами, військовими, посадовцями, майже не повідомлялося, цю тему було табуйовано. Відповідно, поступово формувалося переконання про відсутність цієї гострої соціальної проблеми у СРСР. Тому після мінімуму інформації у радянській пресі про сексуальне насильство, кримінальні хроніки українських газет на початку 1990-х років так шокували громадськість, яка була переконана, що у СРСР такі випадки траплялися украй рідко. У дослідженні ми окреслили і магістральні теми для подальших досліджень українського медіадискурсу (сексуальні домагання на роботі, мілітаризм і сексуальне насильство), і ключові проблеми висвітлення цієї соціальної проблеми (маргіналізація і табуювання, упередженість у доборі фактів, ідеологічна заангажованість в інтерпретації подій тощо). У сучасній Україні тільки впроваджуються норми гендерно чутливої журналістики, тому вивчення цих питань, у тому числі в історичному аспекті, вважаємо актуальним і перспективним напрямком журналістикознавства.

\footnotetext{
31 «За згвалтування арештованої» (1925), Пролетарська правда. 4 липня, вип. 150 (1161), с. 5.

32 Почепцов, Г. (2016), Сучасні інформачійні війни. Київ, Видавничий дім «Києво-Могилянська академія», с. 182.
} 


\section{6. Висновки}

Отже, у медіатекстах 1920-1930-х років проблема сексуального насильства інтерпретувалася крізь призму комуністичної ідеології. Для оприлюднення факту згвалтування у радянських газетах потрібно було, щоб злочин відповідав низці ідеологічних критеріїв, зокрема жертва і гвалтівник мали бути «правильного» класового походження. У газетних текстах перефокусовувалася увага з проблеми сексуального насильства над жінками як повсякденного явища у СРСР на загострення класової боротьби з експлуататорами. У деяких публікаціях журналісти обережно зачіпали тему сексуальних домагань керівників підприємств до робітниць, проте цілісно її не розкривали.

На початку 1920-х років, в умовах становлення радянської влади, повідомлення про сексуальне насильство білогвардійців друкувалися з пропагандистською метою - створити демонізований образ ворога і здобути прихильність місцевого населення. Публіцистична розповідь І. Дубинського про сексуальні військові практики червоноармійців (постійна присутність величезної кількості «своїх» жінок в обозах Червоної армії під час громадянської війни, гвалтування «чужих» жінок) були сміливим винятком із загального журналістського правила замовчування схожої інформації і героїзації Червоної армії.

У 1930-х роках, в умовах посилення сталінського терору, повідомлення про сексуальне насильство у СРСР зникають зі шпальт українських радянських газет. Зате радянських громадян регулярно інформували про схожі злочини у буржуазних країнах.

Завдяки журналістським технологіям (фреймінгу, стереотипізації, накладанню ідеологеми класового ворога на образ гвалтівника, своєрідній авторській інтенціональності, художнім засобам) повідомлення про гендерне насильство набувало необхідного ідеологічного забарвлення. Таким чином, повідомлення про сексуальне насильство в українській радянській пресі комуністична влада розцінювала як ефективну ідеологічну зброю.

\section{СПИСОК ЛІТЕРАТУРИ}

1. Батлер, Дж. (2016), Фрейми війни. Чиї життя оплакують? Київ, Медуза, 276 с.

2. Вороніна, М. (2017), Більшовицький емансипаційний експеримент у 1920-х роках. Кісь О. (Ред.). Українські жінки у горнилі модернізації. Харків, Клуб сімейного дозвілля, с. 106-131.

3. Gill, R. (2009), «Mediated intimacy and postfeminism: a discourse analytic examination of sex and relationships advice in a women's magazine», Discourse \& Communication. № 3 (4), pp. 345-369.

4. Дейк ван, Т. (2013), Дискурс и власть. Репрезентаџия доминирования в языке и коммуникации. Москва, Либроком, 344 с.

5. Дейк ван, Т. (2000), Язык. Познание. Коммуникация. БГК им. И.А. Бодуэна де Куртенэ, Благовещенск, 308 с.

6. Дубинський, I. (1929), «Війна і мир Запорозької дивізії», Червоний шлях, вип. 12, c. $88-108$.

7. «За згвалтування арештованої» (1925), Пролетарська правда. 4 липня, вип. 150 (1161), c. 5. 
8. «Как расправляются с женщинами белогвардейцы» (1920), Работнища и крестьянка. 15 апреля, вип. 3 , с. 3.

9. Лауретис, де Т. (2000), Риторика насилия. Рассмотрение репрезентации и гендера. Гапова Е., Усманова А (Ред.). Антология гендерной теории. Пропилеи, Минск, 2000. $384 \mathrm{c}$.

10. Lazar, M. M (2007), "Feminist Critical Discourse Analysis. Articulating a feminist discourse praxes". https://www.tandfonline.com/doi/abs/10.1080/17405900701464816 (accessed 30 Oktober 2019)

11. Маєрчик, М., Плахотнік, О. (2014), «Гендероване насильство: між звичаєм і злочином». М.Маєрчик, О.Плахотнік, Г.Ярманова (Ред.). Гендер для медій. Підручник із гендерної теорії для журналістики та інших соціогуманітарних спеціальностей. Київ, Критика, 217 с.

12. Мак-Квейл, Д. (2010), Теорія масової комунікації. Львів, Літопис, 538 с

13. «Наймичина доля» (1925), Пролетарська правда. 6 листопада, вип. 255 (1266), с. 3.

14. Нейджел, Дж. (2003), «Маскулінність та націоналізм; гендер та сексуальність у творенні націй», Гентош Л., Кісь О. (Ред.), Гендерний підхід: історія, культура, суспільство. Львів, ВНТЛ-Класика, 250 с.

15. Н.Н., (1925). У цукроварні (м.Іллінці). Пролетарська правда, 1 листопада, № 251 (1262), c. 4.

16. Павлюк, Л.С. (2007), Риторика, ідеологія, персуазивна комунікація. ПАІС, Львів, $130 \mathrm{c}$.

17. «Польський фашистський терор на Західній Україні лютує з неослабною силою» (1931), Вісті ВУЦВК, 18 січня, вип. 16 (3117), с. 2.

18. Почепцов, Г. (2016), Сучасні інформачійні війни. Київ, Видавничий дім "КиєвоМогилянська академія", 504 с.

19. Семотюк, O. (2015), «Аналіз дискурсу vs. контент-аналіз: методично-методологічні відмінності і подібності», Людина. Компютер. Комунікаиія: збірник наукових праць, Львів, Вид-во Львівської політехніки, с. 79-82.

20. Тешанович, Я. (2003), «Жінки і війна», Незалежний культурологічний часопис, № 27, c. 71-88.

\section{REFERENCES}

1. Batler, Dzh. (2016), Frames of war. When is Life Grievable? Meduza, Kyiv, 276 p.

2. Voronina, M. (2017), "Biljshovycjkyj emansypacijnyj eksperyment u 1920-kh rokakh", Kis' O. (Ed). Ukrainski zhinky u hornyli modernizaciyi. "Klub simeinoho dozvillia", Kharkiv, pp. 78-106.

3. Deik van, T. (2013), Discourse and power. Representation of dominance in language and communication. Librokom, Moskva, $344 \mathrm{p}$.

4. Deik van, T. (2000), Tongue. Communication. Cognition. BGK im. I.A.Boduena de Kurtene, Blagoveshchensk, $308 \mathrm{p}$.

5. Gill, R. (2009), «Mediated intimacy and postfeminism: a discourse analytic examination of sex and relationships advice in a women's magazine», Discourse \& Communication. № 3 (4), pp. 345-369.

6. Dubynskyi, I. (1929), "Viina i myr Zaporozkoi dyvizii”, Chervonyi shliakh. issue 12, p. $88-108$. 
7. “Za zgvaltuvannia areshtovanoi” (1925), Proletarska pravda, 4 July, issue 150 (1161), p. 5.

8. "Kak raspravlyayutsya s zhenschinami belogvardeytsyi" (1920) Rabotnitsa i krestyanka. 15 April, issue 3, p. 3.

9. Lauretis de, T. (2000), "The violence of Rhetoric. Considerations on Representation and Gender", Gapova E., Usmanova A. (Ed). Antologiya gendernoi teorii, Propileyi, Minsk, $383 \mathrm{p}$.

10. Lazar, M. M. (2007), "Feminist Critical Discourse Analysis. Articulating a feminist discourse praxes". https://www.tandfonline.com/doi/abs/10.1080/17405900701464816 (accessed 30 Oktober 2019)

11. Mayerchik, M., \& Plahotnyk, O. (2014), “Gender Violence: Between Tradition and Crime", M.Mayerchik, O. Plahotnyk, G.Yarmanova (Ed). Gender for media. A textbook on gender theory for journalism and other socio-humanities, Krytyka, Kyiv, 217 p.

12. Mak-Kvej1, D. (2010), Theory of mass communication. Litopys, L'viv, 538 p.

13. "Naimychyna dolia", (1925), Proletarska pravda, 6 November, issue 255 (1266), p. 3.

14. Neigel, J. (2003). "Masculinity and nationalism: gender and sexuality in the creation of nations", Gentosh L., Kis' O. (Ed). Gender approach: history, culture, society, VNTLKlassyka, Lviv, $250 \mathrm{p}$.

15. N.N., (1925). "U tsukrovarni (m.Illintsi)". Proletarska pravda, 1 November, № 251 (1262), p. 4.

16. Pavlyuk, L.S. (2007). Rhetoric, ideology, persuasive communication. PAIS, L'viv, 130 p.

17. "Polskyi fashystskyi teror na Zakhidnii Ukraini liutuie z neoslabnoiu syloiu" (1931), Visti VUTsVK, 18 January, issue 16 (3117), p. 2.

18. Pocheptsov, G. (2016). Modern information wars, Vydavnychyi dim "Kyievo-Mohylianska akademiia", Kyiv, 524 p.

19. Semotiuk, O. (2015). Discourse analysis vs. content analysis: methodological differences and similarities, Man. Computer. Communication: a collection of scientific papers. L'viv, Vydavnytstvo Lvivskoi Politekhniky, pp. 79-82.

20. Teshanovych, Ya. (2003), "Zhinky i viina", Nezalezhnyi kulturolohichnyi chasopys, issue 27, p. 71-88. 


\title{
THE REPRESENTATION OF SEXUAL VIOLENCE IN THE UKRAINIAN SOVIET PRESS OF THE 1920s AND 1930s: AN IDEOLOGICAL CONTEXT
}

\author{
Olga Khamedova \\ Borys Grinchenko Kyiv University, Ukraine \\ 13 B, Marshal Tymoshenko Str., 04212, Kyiv, Ukraine \\ e-mail: kubg@kubg.edu.ua \\ https://orcid.org/0000-0002-9545-4464
}

The main objective of the study is to determine the specificity of gender representation of violence against women in the Ukrainian Soviet press of the 1920s and 1930s. The methodology of our study combining discourse analysis with feminist criticism. In the texts of the media of the 1920s and 1930s, the problem of sexual violence was interpreted in line with communist ideology.

In order to publicize the fact of rape in Soviet newspapers, it was necessary for the crime to meet a number of ideological criteria, in particular the victim and the rapist had to be of the "right" class origin. Newspaper texts focused on the issue of sexual violence against women as an everyday occurrence in the USSR to exacerbate the class struggle against exploiters. In some publications, journalists carefully touched on the subject of sexual harassment by business executives, but it was not fully disclosed.

In the early 1920s, under the conditions of Soviet rule, reports of sexual violence by White Army soldiers were printed with propaganda goals to create a demonized image of the enemy to gain the affection of the local population.

I. Dubinsky's publications on the sexual military practices of the Red Army (the constant presence of a large number of «their» women in the Red Army during the Civil War, the rape of «foreign» women) were a bold exception to the general journalistic rule of concealing such information. In the 1930s, with the height of Stalin's terror, reports of sexual violence disappeared from the front pages of Ukrainian Soviet newspapers. But Soviet citizens were regularly informed of similar crimes in bourgeois countries.

Research results. In our study we outline the main topics for further research of Ukrainian media discourse (sexual harassment at work, militarism and sexual violence), as well as the key issues of coverage of this social problem (marginalization and taboos, ideological involvement, bias, etc.).

Conclusions. Thanks to journalistic technologies (framing, stereotyping, imposing of a class enemy ideologue on the image of a rapist, a kind of authorial intentionality, artistic means), the message about gender violence acquired the necessary ideological coloring. Thus, reports of sexual violence in the Ukrainian Soviet press were regarded by the communist authorities as an effective ideological weapon.

Significance. Gender-sensitive journalism is only being implemented in modern Ukraine, so we consider these issues, including historical aspects, to be a topical and promising area of media studies.

Key words: sexual violence; gender violence; rape, the press; propaganda, ideology. 